\title{
Correction to: High rhesus (Rh(D)) negative frequency and ethnic-group based $A B O$ blood group distribution in Ethiopia
}

Lemu Golassa ${ }^{1 \dagger}$, Arega Tsegaye ${ }^{2 \dagger}$, Berhanu Erko $^{1}$ and Hassen Mamo ${ }^{3^{*}}$

\section{Correction to: BMC Res Notes (2017) 10:330}

https://doi.org/10.1186/s13104-017-2644-3

Following publication of the original article [1] the authors reported that the information in Ref. [32] had been misquoted. The Rh factor in one region in Saudi Arabia is $8.8 \%$, not $29 \%$ as stated.

\section{Author details}

${ }^{1}$ Aklilu Lemma Institute of Pathobiology, Addis Ababa University, P.O. Box 1176, Addis Ababa, Ethiopia. ${ }^{2}$ Jimma University, P.O. Box 378, Jimma, Ethiopia. ${ }^{3}$ Department of Microbial, Cellular and Molecular Biology, College of Natural Sciences, Addis Ababa University, P.O. Box 1176, Addis Ababa, Ethiopia.

The original article can be found online at https://doi.org/10.1186/ s13104-017-2644-3.

\section{Publisher's Note \\ Springer Nature remains neutral with regard to jurisdictional claims in pub- lished maps and institutional affiliations.}

Received: 7 March 2018 Accepted: 7 March 2018

Published online: 14 March 2018

\section{Reference}

1. Golassa L, Tsegaye A, Erko B, Mamo H. High rhesus (Rh(D)) negative frequency and ethnic-group based $\mathrm{ABO}$ blood group distribution in Ethiopia. BMC Res Notes. 2017;10:330. https://doi.org/10.1186/s1310 4-017-2644-3.

*Correspondence: binmamo@yahoo.com; hassen.mamo@aau.edu.et

${ }^{\dagger}$ Lemu Golassa and Arega Tsegaye have contributed equally to this work

${ }^{3}$ Department of Microbial, Cellular and Molecular Biology, College

of Natural Sciences, Addis Ababa University, P.O. Box 1176, Addis Ababa,

Ethiopia

Full list of author information is available at the end of the article 